CURRENT RESEARCH JOURNAL OF HISTORY

(ISSN -2767-472X)

VOLUME 03 ISSUE 01 Pages: 14-20

SJIF IMPACT FACTOR (2021: 5. 505)

OCLC - 1243560778 METADATA IF - 6.458

Crossref do

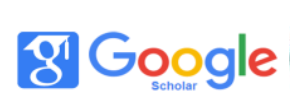

10

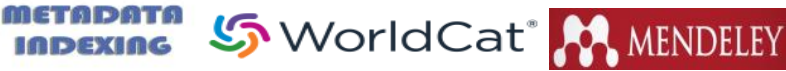

Publisher: Master Journals

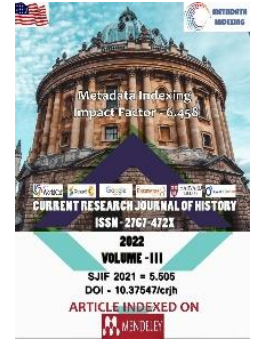

Journal Website: https://masterjournals. com/index.php/crih

Copyright: Original content from this work may be used under the terms of the creative commons attributes 4.0 licence.
Research Article

\section{INFORMATION ON THE ECOLOGICAL SITUATION AND WATER DISTRIBUTION IN TASHKENT IN “PAST AND CURRENT HISTORY OF TASHKENT" BY A.I. DOBROSMYSLOV}

\author{
Submission Date: December 27, 2021, Accepted Date: January 07, 2022, \\ Published Date: January 18, 2022 \\ Crossref doi: https://doi.org/10.37547/history-crjh-03-01-04 \\ Ravshan Tursunov \\ Candidate of Historical Sciences, Associate Professor, National University of Uzbekistan named after \\ Mirzo Ulugbek, Uzbekistan
}

\title{
ABSTRACT
}

This article examines the ecological situation in the Tashkent region in the second half of the XIX - early XX centuries, the duties and responsibilities of irrigators, canal elders and mirabs in the distribution of water resources and water.

\section{KEYWORDS}

Ecological situation, water resources, rivers, canals, floods, rational use of water, irrigator, mirab.

\section{INTRODUCTION}

In the 19th and early 20th centuries, a number of scientists and specialists were sent to Turkestan by the Russian Empire to study the history of the region, its natural and geographical location and riches. One such representative is a member of the Russian Geographical Society, Russian historian and ethnographer A.I. Dobrosmyslov (1854-1915), including the history of the Turkestan region, He wrote valuable information about the history of Tashkent and the cities of Syrdarya region. His work "Tashkent's Past and Present History" in the mid-nineteenth and early twentieth centuries is an important resource for a 
CURRENT RESEARCH JOURNAL OF HISTORY

(ISSN -2767-472X)

VOLUME 03 ISSUE 01 Pages: 14-20

SJIF IMPACT FACTOR (2021: 5. 505)

OCLC -1243560778 METADATA IF - 6.458

Crossref d
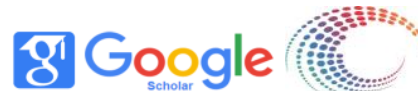

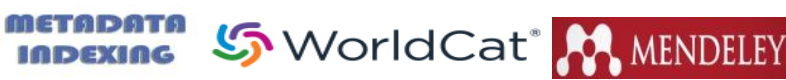

Publisher: Master Journals

comprehensive study of socio-economic and environmental history. Also, natural phenomena that took place in the Turkestan region in the early twentieth century, including Tashkent, Theoretical and practical work on its consequences and disaster management, Important environmental issues such as climate and weather have also been regularly published in periodicals [1, p. 570-574].

\section{THE MAIN RESULTS AND FINDINGS}

According to A.I. Dobrosmyslov, The territory of Tashkent has an area of 18,325 hectares and is irrigated by water from the Chirchik River through the Bozsuv Canal [2, P.168]. The beginning of the Chirchik goes to the mountains and passes through several villages to the point where it flows into the Bozsuv canal, due to the speed of the flow, it is almost not polluted and leads to mountain water, which is formed when the snow melts. Across Tashkent, it crosses the Niyozbek Dam, 31 miles to the Labzak Gate, and divides into the Bozsuv, Kaykovuz, and Anhor canals. They, in turn, were divided into canals, the names of which are given below, which supplied the city with water, and which was poured into the general Bozsuv canal outside the city. Bozsuv, in turn, flows through China $(66 \mathrm{~km}$ from Tashkent) to the Syrdarya.

It is distributed from Bozsuv canal to Karasuv, Salar, Anhor, Kaykovuz, Yalongach, Gadragon, Ivish, Kungrad, Darvozakent, Baytikurgan, Uymaut and Yuz canals. All of these canals are main canals, from which the 2 nd level canals are separated.

The Russian Empire did not refrain from committing atrocities in order to colonize Turkestan. In particular, According to A.I. Dobrosmyslov, in order to capture Tashkent in 1865, General One of the first orders given by M.G. Chernyaev to his troops coming from Niyazbek was the task of destroying these irrigation facilities [3,
P.136]. Due to the damage to water systems, Russian troops can easily capture the city [4, B.60].

General M.G. Chernyaev's actions, that is, the disruption of the entire irrigation system on the right bank of the Chirchik River, As a result, the ecological environment in Tashkent will be seriously damaged. Due to the demolition of irrigation facilities, water did not reach Tashkent for a long time. Urban residents suffer greatly from dehydration [5, p.20]. Imperial officials, whose main goal was to colonize Turkestan in a short period of time, paid little attention to rebuilding the destroyed irrigation facilities. Representatives of the empire, unfamiliar with the needs of the indigenous population, viewed the objections of the townspeople as unreasonable whims, "If they need water, let them take it for themselves" [6, p.137].

Russian historian A.I. Dobrosmyslov describes the deplorable state of the water situation in Tashkent as follows: "We know that he was indifferent to this, as the only Gadragon canal that supplied water to the Horde (the central fortress of Tashkent) was completely dry and dry. At that time, the Russians were living in the cells of the Sartar fortress in Orda. Water was taken from Gadragon for drinking. In Gadragon, which was covered with a canopy, there were mailcarrying horses carrying messages from Orenburg. One of the officials (Arkhangelsky, the regional auditor) even built a house for himself in front of the canal" [7, p.137].

A.I. Dobrosmyslov assessed the ecological situation in Tashkent, that such indifference to irrigation continued until 1867, explaining their plight to the indigenous military sergeant-at-arms, that they have asked for help, that the environmental situation is deplorable, Rakat said that they were not allowed to work in the Governor's Garden, where the dam is located, and that the Gadragon canal could not be 
CURRENT RESEARCH JOURNAL OF HISTORY

(ISSN -2767-472X)

VOLUME 03 ISSUE 01 Pages: 14-20

SJIF IMPACT FACTOR (2021: 5. 505)

OCLC - 1243560778 METADATA IF - 6.458

Crossref
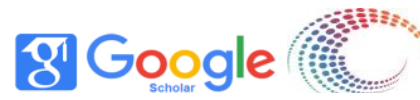

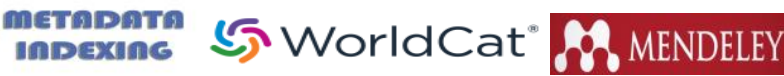

Publisher: Master Journals

drained because the canal was busy, They said that they did not have the capacity to re-strengthen the Zakh-Ariq and Bozsuv and to correct the flow of water, that there was no organization to help them, however, it states that officials are required to repair waterworks $[8, \mathrm{p} .137]$.

Some measures will be taken to address the problems raised by the indigenous population in their requests for water supply to the city. It should be noted that the focus on irrigation facilities in Tashkent and their repair will be controlled by the arrival of General vonKaufmann in government. In 1868 a decree was drawn up by the public economic departments of Tashkent and Chirchik. It was decided to ask the mayor to organize proper control work for the irrigation system on the right bank of the Chirchik River, which was damaged and not restored due to military operations.

At the suggestion of the mayor E.A. Rossitsky, technologist N.F. Ulyanov was appointed to regulate irrigation works on the right bank of the Chirchik River, 1,500 rubles a year will be allocated for its maintenance, and 5 canal elders will be attached to it as assistants. Four of the elders were from the indigenous part of the city, and one was from the Russian part. Under the command of each elder were 6 mirabs and 2 dams. Aryk elders had an annual supply of 400 rubles, a dam 300 rubles, and a mirob 100 rubles [9, p.138].

Irrigation facilities on the right bank of the Chirchik River, destroyed by General M.G. Chernyaev, were regulated during 1868 and 1869 [10, p.30]. Parts of the coast destroyed by Russian troops will be completely leveled, and ditches filled with small stones will be cleared. Niyozbek dam will be reconstructed. Not only was the entire city supplied with water, but in 1870 it was possible for the population of the area to return to agricultural work. This is because part of the Chirchik waters flowed through the Zakh-aryk into the valley along the Keles River in the village of Qoplonbek. Along with this capital construction, people from all regions of Tashkent district will take part in the cleaning of the Zakh-aryk. More than 12,000 workers work in 14 days to clean the canal [11, p.138]. At the same time, in the part of the city, which was formerly the center of Orda and Kashgar, and later inhabited by Russians, work is being carried out to gradually build canals in the streets.

In order to regulate the proper distribution of water in the city, a separate Arik Committee was established on July 11, 1868 in the Russian-populated part of the city. The committee was staffed by Captain D.I. Svishevsky is appointed observer. He is responsible for overseeing the implementation of the Regulations on the distribution and proper use of water [12, p.139].

According to the regulations, homeowners will be fined if violations of the rules established during the use of water are detected. Of course, the introduction of these procedures in water use has encouraged the population to use water resources wisely.

For example, it was not possible to throw any rotten, any dirty things into the main and additional canals. If the owner of the apartment does not remove the waste within 1 or 2 hours after the application submitted by the officials, then the first time he was fined 3 rubles, the second 6 rubles, and the third time 9 rubles, ie 3 rubles each. Half of the fine levied on the landlord was in favor of the elder [13, p.144].

Since it is not possible to determine the exact rules for the water used for construction, each person constructing will have to pass a waterway in the size and appearance determined by the responsible officer who was notified in advance of the construction. A person who did not follow this rule was fined 3 rubles 
CURRENT RESEARCH JOURNAL OF HISTORY

(ISSN -2767-472X)

VOLUME 03 ISSUE 01 Pages: 14-20

SJIF IMPACT FACTOR (2021: 5. 505)

OCLC - 1243560778 METADATA IF - 6.458

Crossref do
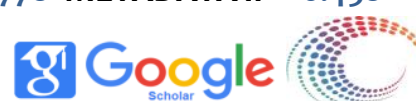

metadata (5. WorldCat

Publisher: Master Journals

the first time, 5 rubles the second time, and 10 rubles the third time, as is often the case. In the fourth, he was deprived of water for a total of 30 days. After the expiration of the term, for new violations were fined in the same order, ie from 3 rubles.

The bridges over the main canals had to be kept clean and in good condition. Failure to comply was punishable by a fine of 1 ruble 50 tiyn the first time and 2 rubles 50 tiyn the second time.

The main and large canals could not be blocked by any obstacles. A fine of 15 rubles was imposed for the first time for blocking the main canal, plus 1 ruble for each subsequent case. A person who obstructed the main canal was fined 2 rubles for the first time and 2 rubles for the latter [14, p.145].

On June 19, 1877, General von Kaufmann approved a new regulation on the distribution of water in the country, the "Temporary Regulations on Irrigation in Turkestan" in order to ensure the correct and rational use of water [15, p.151]. These rules also applied to Tashkent. This Regulation requires special attention to the following aspects in the process of water use and distribution: 1). Water from canals, canals and streams belonged to the state treasury, but the population had to follow a number of rules for the right to irrigate the land. The control of water distribution in the irrigation of lands is carried out by the local administration, and all the remaining water is used for the benefit of the whole country, at its own discretion, to meet the needs of landowners; 2). New lands that are not irrigated at all are permitted only by the governor and the governor-general to carry water from rivers and lakes, dig ditches, drain swamps, and build canals on vacant lands that are not owned by anyone. Water supply to factories and plants is permitted only by the governor; 3). It is prohibited to change the water intake devices of large and small canals or the level of dams and reservoirs without the permission of an irrigator for any reason and excuse. If necessary, the irrigator applies to the governor for permission; 4). Currently, rice cultivation is prohibited in unauthorized areas. Planting rice in new areas is permitted by the governor if it is found by the health authority to be hygienically harmless, which is unquestionably important to the health of the population; 5). The construction of factories and plants is permitted by the governor only if it is possible to avoid damage to water quality, away from residential areas, along rivers and water canals; 6). If the landowner at the top of the canal and ditch line voluntarily blocks the water, the remaining landowners may require the ditch elder to take action immediately or the next day based on claims made. If the landowner who blocked the water at the request of the elder does not disclose the water, an act is drawn up in the presence of the affected landowner and the mirab or one witness. With this act, the judge or judge who decides on the landlord may apply for a fine from the offender or for assistance to the injured landlord in recovering damages; 7). All disputes and disputes between landowners over water use shall be settled by judges or magistrates, depending on who they belong to; 8 ). Depending on the violation of the rules established by the landowner, as a result of which the dam, canal and other irrigation facilities were destroyed, the amount of the fine established by law, that is, they are prosecuted on the basis of the type of punishment imposed by the judges and magistrates, depending on the offense committed; 9). Landowners need to make sure that the water in the canals and ditches that run through their land is not polluted, that waste is not falling on them, and that it is clean. Cleaning the water from growing grasses, muddy, muddy and organic sediments is part of the public task of carrying out landscaping works, etc. [16, P.151-155]. 
CURRENT RESEARCH JOURNAL OF HISTORY

(ISSN -2767-472X)

VOLUME 03 ISSUE 01 Pages: 14-20

SJIF IMPACT FACTOR (2021: 5. 505)

OCLC - 1243560778 METADATA IF - 6.458
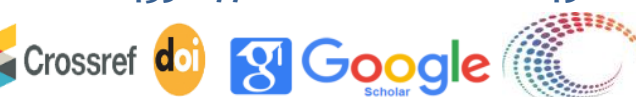

metadata (5) WorldCat

Publisher: Master Journals

According to A.I. Dobrosmyslov, the country has developed guidelines for those who manage irrigation facilities, which define the duties and responsibilities of the irrigator and his assistants.

The irrigator should control the volume of all water entering the area under its jurisdiction and its even distribution. To do this, he had to perform the following tasks: a). Compile a detailed map of all water sources, the system of canals and ditches coming out of them in the size of 1 verst, all separate areas irrigated by large terminal canals, if possible, should map several large areas of the same size. The size of such projects is determined at its discretion, in a way that is fully visible and understandable; $b$ ). Determine the amount of water coming from each waterway in the same area by measuring and checking and pouring into each canal separately at a given time; $v$ ). Determining and measuring the area of irrigated land with one or more canals; g). Calculate the amount of water used by plants, used by people and animals, or used to irrigate each area for other needs; d). Identify the excess water from the irrigation of the area and the new area where that water can be irrigated; e). Measure the area of non-irrigated lands with the help of special tools, calculate their costs and benefits, develop a project for their irrigation; j). The work to be done under the program must be completed during the year and submitted to the head of state of the country for consideration by the military governor by February 1 of the following year; $z$ ). Through the ditches at the disposal of the irrigator, mirabs and dams, the suitability of the plot, basins and ditches, the maintenance of the normal water level in the canals and ditches, control over the equal and correct distribution of water among landowners, the gradual development of rules for water use; i). If water users fail to perform their duties in clearing ditches, mowing grass around them, and repairing shores, dams, ponds, and other structures, the irrigator should seek police assistance. It is mandatory to comply with these requirements, etc. [17, p.158-160].

In general, based on the above-mentioned obligations and responsibilities, the irrigator should work diligently and according to a clear and definite plan without thinking of personal interests and needs. Then everything that was done was ready-made material and had to serve as a guide for future professionals who did not know the local area well at all.

It is the responsibility of the mirabs to manage a specific irrigation network in each ditch. Mirabs are directly subordinate to their elders in the management of dams and water management in their allotted plots and are obliged to perform their duties. The mirabs had to fulfill the following obligations within their plot: a). Water supply for the lands of the population and landowners under its direct control or in person in accordance with local custom or in the prescribed manner; b). Control and prevent water from being wasted, swamps and mud in the streets, highways, fields and vacant lands in a useless way; v). Preventing water from being trapped and trapped; g). Strict control over the cleanliness of the water in the canals, to prevent the presence of various wastes and pollutants in them, thereby ensuring that they do not endanger the health of the population; d). Require water-using landowners, organizations and farms to clean canals in a timely manner from sand, algae, various unwanted plants and sediment; e). Personally monitor the correctness and quality of work in canals, dams, ditches and ditches during cleaning and repair works; j). It was considered right to apply to the local administration or to inform the elder to open the dams and ditches if necessary to protect the banks of the canals from damage caused by floods, mudslides and accumulation of water [18, p.178]. 
CURRENT RESEARCH JOURNAL OF HISTORY

(ISSN -2767-472X)

VOLUME 03 ISSUE 01 Pages: 14-20

SJIF IMPACT FACTOR (2021: 5. 505)

OCLC - 1243560778 METADATA IF - 6.458

Crossref dol gु Google

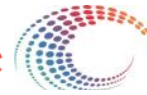

metคDคT!

Imbexing

5) WorldCat

Publisher: Master Journals

\section{CONCLUSION}

In short, in the mid-nineteenth and early twentieth centuries, the process of using water resources in the territory of Tashkent was carried out in a chaotic manner, it also had an impact on the ecological condition of the city. In order to find a solution to these problems and eliminate them, the Governor-General of Turkestan has taken a number of measures, that is, regulations, guidelines and procedures have been developed for the use and distribution of water.

In a detailed study of the history of Tashkent, its natural and geographical location, water resources and processes of their use Russian historian and ethnographer "Past and Present History of Tashkent" by A.I. Dobrosmyslov serves as an important historical source.

\section{REFERENCES}

1. Tursunov R. Ecological condition and mysteries in Turkestan periodical press in the early $\mathrm{XX}$ century (in the case of Sadoi Fergana newspaper) // ISJ Theoretical \& Applied Science, Philadelphia, USA. 2019, 05(73), - P. 570-574.

2. Tursunov R. The research analysis of the socioeconomic issue of the Turkestan Jadids in the beginning of the 20 th centry // Central Asian Problems of Modern Science and Education. 2019, 4 (2), -P. 337-348.

3. Tursunov R. The "Sadoi Fergana" newpaper the most important historical source in the lighting of socio-economic processes in Turkestan. // International Journal of Information Research and Review. 2019, 2 (6), P. 6154-6155.

4. Tursunov R. Coverage of the ecological situation in Turkestan in the memoirs of
Sadriddin Ayni. // Pedagogy and modern education: tradition, experience and innovation, International Scientific and Current Research Conference. - USA. 2021. - P.19-23.

5. Турсунов Р. Воззрения национальных прогрессистов на социально-экономические процессы в Туркестане в начале XX века. Автореф. дисс. канд. ист. наук.- Тошкент. 2008. $30 \mathrm{C}$.

6. Добросмыслов А.И. Ташкент в прошлом и настоящем. - Тошкент, 1912. - С.168.

7. Добросмыслов А.И. Ташкент в прошлом и настоящем. - Тошкент, 1912. - С.136.

8. Алимова Д.А., Филанович М.И. Тошкент тарихи. (Қадимги даврлардан бугунги кунгача) - Тошкент: “ART FLEX”, 2009. - Б. 60.

9. Зияев Х. Ўзбекистон мустамлака ва зулм исканжасида (XIX асрнинг иккинчи ярми - XX аср бошлари) Тошкент: “Шарқ”, 2006. - Б. 20.

10. Добросмыслов А.И. Ташкент в прошлом и настоящем. - Тошкент, 1912. - С.137.

11. Добросмыслов А.И. Ташкент в прошлом и настоящем. - Тошкент, 1912. - С.137.

12. Добросмыслов А.И. Ташкент в прошлом и настоящем. - Тошкент, 1912. - С.137.

13. Добросмыслов А.И. Ташкент в прошлом и настоящем. - Тошкент, 1912. - С.138.

14. Исмоилова Ж. XIX асрнинг иккинчи ярми - XX аср бошларида Тошкентнинг “янги шахар” қисми тарихи. - Тошкент: “Fan va texnologiya", 2004. - Б. 30.

15. Добросмыслов А.И. Ташкент в прошлом и настоящем. - Тошкент, 1912. - С.138.

16. Добросмыслов А.И. Ташкент в прошлом и настоящем. - Тошкент, 1912. - С.139.

17. Добросмыслов А.И. Ташкент в прошлом и настоящем. - Тошкент, 1912. - С.144.

18. Добросмыслов А.И. Ташкент в прошлом и настоящем. - Тошкент, 1912. - С.145. 
CURRENT RESEARCH JOURNAL OF HISTORY

(ISSN -2767-472X)

VOLUME 03 ISSUE 01 Pages: 14-20

SJIF IMPACT FACTOR (2021: 5. 505)

OCLC - 1243560778 METADATA IF -6.458

Crossref do

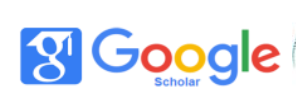

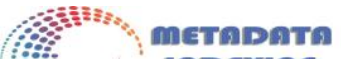

19. Добросмыслов А.И. Ташкент в прошлом и настоящем. - Тошкент, 1912. - С.151.

20. Добросмыслов А.И. Ташкент в прошлом и настоящем. - Тошкент, 1912. - С.151-155.

21. Добросмыслов А.И. Ташкент в прошлом и настоящем. - Тошкент, 1912. - С.158-160.

22. Добросмыслов А.И. Ташкент в прошлом и настоящем. - Тошкент, 1912. - С.178.

23. Tursunov R. Ecological condition and mysteries in Turkestan periodical press in the early $X X$ century (in the case of Sadoi Fergana newspaper) // ISJ Theoretical \& Applied Science, Philadelphia, USA. 2019, 05(73), - P. 570-574.

24. Аширов А. Ўзбек маданиятида сув. Тошкент: Akademnashr, 2020. - Б.181. 